\title{
Scale to Measure the Determining Factors for Reporting Wrongdoings in the Public
}

\author{
Sector Universities \\ * Nargis Abbas, Assistant Professor (Corresponding Author) \\ ** Uzma Ashiq, Lecturer \\ **** Maria Yaqoob, PhD Scholar
}

\begin{abstract}
Reporting wrongdoing is significant to the effectiveness of the organization, however, is a challenging task. The objective of this study was to contribute to the research by identifying the determining factors that influence the decision of a faculty member to report unethical behavior in the public sector universities. Further, to develop the validated scales to measure such factors. To achieve these objectives, this research study adopted a two-phase, exploratory sequential mixed method research design. A multistage sampling technique was used and a sample of 300 faculty members from four public sector universities of the Punjab were selected. The first part of the study was a qualitative phase to explore the dimensions by using semi-structured interviews and a focused group discussion method in which five dimensions were explored. With a 42-item Whistle-blowing Procedure Questionnaire was created. In the second phase, in the quantitative phase, six factors connected to the theoretical constructs of decision of reporting wrongdoings/whistle-blowing were explored in the scale construction and validation process by using exploratory factor analysis.
\end{abstract}

Keywords: Whistle-blowing, Internal Reporting, External Reporting, Whistle-blower, Higher Introduction Education Institutions, Punjab

Reporting procedure is a significant tool in revealing wrongdoings and controlling corruption and fraud, however it can be an arduous and challenging task that few are willing to adopt. Employees who adopt to report the wrongdoings are often subject to retaliation, loss of services, and defamation of character (Abbas \& Ashiq, 2020). Despite the costs associated with the reporting of the wrongdoings, some individuals are ready to come forward about these illegal, unlawful, or unethical, acts. Literature has documented the specific term 'whistle-blowing' for reporting the wrongdoings (Pittroff, 2016; Edwards et al., 2009; Miceli \& Near, 1992). Less work is witnessed in this particular phenomenon in the Pakistani context, too specifically in the public sector universities (Abbas \& Ashiq, 2020). On the other side of the world, that is in developed countries like the US, it has been a very extensive and multidisciplinary area of research since the 1970s. Subsequently, a mostly recommended whistleblowing definition is as below;

"The disclosure by organizational members (current/former) of unethical/ immoral, illegal, or illegitimate and unlawful practices under the control of their employers to individuals or organizations that may be able to take action" (Miceli \& Near, 2009, p. 15).

Most companies, industries, and organizations currently developed the whistle-blowing system, among which the system used by aviation is yet to be known as the most efficient system. A wide range of researches on whistle-blowing has been done in America too particularly in the corporate sector. Albert Hirschman (1970) was the first in this field, who discussed different courses of action when a worker sees wrongdoing and corruption in his/her own organization's workplace. He stated three alternatives for action: i) protest and complaints as voice (voicing one's dissatisfaction); ii) Loyalty (remaining silent and loyally continuing to work); and iii) to exit, (to leave the organization).

Organizations have taken serious steps to establish separate departments for reporting the wrongdoings (Ewing, 1983). Most of the companies have set codes of ethics that may encourage the

* Department of Education, University of Sargodha

** Department of Social Work, University of Sargodha

*** Department of Education, University of Sargodha 
workers to inform the organization's legal counsel when they see illegal and unethical activities within the working place (Mathews, 1987). The organizations that introduced the whistle-blowing system are performing effectively as compared to those organizations where employees are not encouraged to raise the voice against the wrong decisions or misdeed of the higher officials (Carroll \& Buchholtz, 2000). The main motive of whistle-blowing is to eliminate illegal behavior in the organization. Whistle-blowing is a significant subject; it may be a shield against the harmful environmental effects due to the wrongdoings for an organization (Weiss, 2006; Appelbaum et al., 2006). Reporting the wrongdoings, which occur in the private as well as public sectors, is an effective way for encouraging employees to consider it as organizational obligations (Rothschild \& Miethe, 1999; Stewart, 1996; Keenan, 1995). It was also observed that wrongdoings are not being reported in a well-defined mechanism due to the fear of the reaction against the reporter by the authorities. Because supervisors considered such reporters as the source of harm for them (Weinstein, 1979). Therefore, due to the fear that perhaps management would take negative action against the reporters, prevent them to report the unnatural corrupt events or unethical issues to the authority (Kaplan et al., 2010; Miceli, Near, \& Dworkin, 2009).

Therefore, to overcome these discrepancies, organizations must implement actual internal policies and plans for the anticipation, revealing, and inquiry of immoral behavior. Internal reporting by the head of the institution and employees on the conduct of colleagues is considered to be the most effective strategy for detecting misconduct in an organization (Drugs \& Crime, 2006). However, a series of factors that constrain internal reporting has been identified in the research. In the exploration of factors that encouraged reporting within the organization, Wortley et al. (2008) recognized unethical behavior that had been observed through 5241 employees (as a sample) from of public sector organization. The workers were categorized according to actions they have taken in response to their observations; most of them had reported the wrong behavior privately because the reporting is conditioned with the reputation of the organization, while others reported internally and many of them didn't report. Explaining the reasons, the researchers stated the reason of either fear of worst consequences or belief that the matter would not be taken seriously.

Therefore, previous researches documented that there is a need for a valid and authentic tool to measure the various dimensions of the wrongdoings in organizations. The existing literature indicated that research in this area is limited specifically the exploration of factors that can be the reason to blow the whistle (Brown \& Head, 2005; Dekker, 2003). However, some factors were identified that were considered to influence the reporting decision were drawn from the past researches (Abbas \& Ashiq, 2020; Donkin, et al., 2008; Wortley, et al., 2008; Zipparo, 1999; Miceli $\&$ Near, 1984). The mentioned factors were: Perception about reporting procedure; Awareness of reporting procedures; Trust that identity of respondent would remain confidential; Belief that authority would take action in response to the report; Belief that enough support would be provided to the complainant.

To summarize, the lack of empirical studies along with the lack of available scales to measure the determining factors has impelled this study. Hence, this study aimed to develop a scale to measure the determining factors which influence the employees' decision to report or raise their voice against corrupt, unethical issues or wrongdoings in the public sector universities in Pakistan.

\section{Methodology}

It was realized that there was a great need for the development of a scale to measure the determining factors that influence the decision of a faculty member to report the wrongdoing or whistle-blowing in public sector universities. Exploratory sequential mixed methods research design was applied for this study. The exploratory design is commonly used to explore a phenomenon, categorize themes, design an instrument, and subsequently test it (Creswell, 2012). The current study applied two-phase methods of research design with its emphasis on "Collecting, analyzing, and mixing both quantitative and qualitative data in a single study" (Creswell \& Clark, 2007; p. 5).

This research method was based on the research work of Seth et al. (2006) adopted for the development of SSQSC ${ }^{1}$. The research data was collected through interview protocol, focused group discussion, and a questionnaire conducted in public universities of Punjab Pakistan.

\footnotetext{
${ }^{1}$ Supplier Service Quality in Supply Chain
} 
The population of the study was all the public sector universities of the Punjab province. A multistage sampling technique was adopted for selecting the sample of the study. At the first stage, four universities were selected randomly (Punjab University Lahore, G.C University Faisalabad, University of Agriculture Faisalabad, and University of Sargodha). In the next stage, teaching faculty members were selected through purposive sampling technique by using the inclusion criterion. Therefore, those faculty members who knew the concept of whistleblowing were selected from the sampled public sector universities of Punjab. A total of 4 faculty members from 4 universities were selected for interview (one faculty member from each university). Afterward, a Total of 14 faculty members from two universities ( 8 from the University of Sargodha and 6 from the University of the Punjab, Lahore) participated in two FGDs. Lastly, for exploring the factors and reliability of the scales, 200 respondents were selected through convenient sampling.

Procedure: The scale development procedure to develop a valid and reliable scale initiated with a qualitative study to explore the dimensions of the whistle-blowing reporting procedure. Primary dimensions were attained through literature review. But, there was no sufficient information about the perception of employees related to the whistle-blowing reporting procedure in Pakistan, and it was considered that it's essential to conduct a qualitative research study to fill the gap.

Qualitative Part: The qualitative part was consisted of examining the determining factors of wrongdoing reporting procedure which were produced by literature review and concerning the illustration portrayed by selected university faculty members. To analyze qualitative research a phenomenological approach has been used to explore the dimensions and items.

Interview procedure: For better understanding about the significant factors for whistle-blowing in the public universities, four semi-structured interview protocols were conducted. Each interview lasted for 15-20 minutes. Permission was taken by the researcher from each interviewee to record the interview with the assurance of privacy and confidentiality of the data provided. Data was analyzed and four major themes were generated for the FGD.

Focus Group: Two focused group discussions (FGD) were conducted in two universities after interview protocols. Eight experienced faculty members participated in each Focused Group Discussion. Audio-recording was developed with the permission of the participants. FGDs were continued for almost 2 hours. The discussion centered on the four major dimensions in the FGD lead by the interviews, these were the dimensions; (a) perceptions about whistle-blowing reporting (b) importance of reporting procedure, (c) standard of operating procedure of whistle-blowing reporting at the international level, and (d) suggestion to improve the reporting procedure in the public universities of Punjab, Pakistan.

Data Analysis for the qualitative part: Transcriptions were analyzed through the steps of the Phenomenological data analysis process given by Moustakas (1994). Creswell (2012) and Moustakas (1994) suggested the phenomenological data analysis into three parts; phenomenological reduction; imaginative variation; and construction of the essence of the experience. Phenomenological, a qualitative inquiry approach focuses on the exploration of the phenomenon. This phenomenon is explored by the participants' narrative descriptions of their respective experiences. In this study, four major themes were generated from the semi-structured interviews after transcribing the interviews of the experts. All interviews and focused group discussions, recordings were transcribed verbatim and fictitious identification codes were allotted to the participants. In the phase of Phenomenological reduction, the data obtained from the semi-structured interviews and FGDs were clustered into the themes after removing the overlapping or repetitive statements. Afterward, these clusters of themes were converted into textual descriptions. In dealing with Imaginative variation, the experiences and views shared by the participants which were converted into textual descriptions, were then constructed into the structural description. After in-depth reading the transcriptions of all the interviews, the most important statements were extracted from each interview transcription. Lastly, to "construct the essence" of the given phenomenon of determining factors of reporting of wrongdoings, statements with the same structure/dimension were grouped were written.

\section{Procedure of Scale Development:}

The guidelines proposed by DeVellis (2003) were followed to develop the questionnaire.

Step 1: Defining the Domain of Construct: The findings of the first qualitative part were, defining the dimensions of determining factors of reporting wrongdoings by the transcribing of participant's interviews. An initial list of dimensions was developed by transcribed data which were compared with 
the literature-generated dimensions. The results of the interviews confirmed the dimensions generated from the literature. Therefore, both results recommended that determining factors that influence the decision about the reporting wrongdoings consists of five dimensions, these are: (1) Perception about reporting procedures, (2) Awareness about reporting wrongdoings system (3) Trust that the identity of the complainant would remain confidential (4) Belief that authority would take unbiased action in response to a report (5) Belief that enough support would be provided to the complainant.

Step 2: Generate an Item Pool: With a careful consideration of literature as well as qualitative results of the qualitative part, a list of 77 items measuring the five determining factors were generated. Items were separated for each factor.

Step 3: Initial Item Purification: To ensure the face and content validity of the generated items pool, the selected research experts reviewed and refined the items concerning their factors. The recurring items measuring the same idea, or theoretically weak items were deleted. Finally, the items were reduced from 77 to 60 items for 5 factors.

Step 4: Appropriate Scale for Measurement: Seven-point Likert scale varies from " $1=$ Strongly Agreed" to "7=Strongly Disagreed" was selected for measuring the level of agreement.

Step 5: Validation of research instruments: The scales were refined with accredited content validity which is evaluated through the results and feedback by a team of experts. The items were either rewritten or deleted which were not measuring the true essence of the deduced factors. The remaining items for proceeding with the reliability measurement were 52 .

Step 6: Administered pilot test to Test the Reliability of scales: A Pilot study was conducted with a sample of 50 faculty members selected from the sampled university.

Data Analysis and Results

Data collected in the pilot study were entered into the data file of SPSS v.22. the data were refined by checking the outliers and handled the missing values with the estimated means.

The reliability of the instrument was calculated through Cronbach Alpha. Factor-wise reliability coefficients for each factor were calculated given below in the table.1 which, Therefore, showed that the questionnaire was reliable for collecting core data for the study.

Table 1. Measurement of Reliability through Cronbach Alpha

\begin{tabular}{llll}
\hline Item & Factor & N. of Items & $\begin{array}{l}\text { Cronbach } \\
\text { Alpha }\end{array}$ \\
\hline 1 & Perception about reporting procedure & 11 & .742 \\
2 & Awareness of reporting procedure & 12 & .761 \\
3 & Trust that identity of the complainant would remain confidential. & 6 & .736 \\
4 & Belief that authority would take action in response to a report & 5 & .865 \\
5 & Belief that enough support would be provided to the complainant & 8 & .853 \\
\hline
\end{tabular}

In this part, those items which didn't load the alpha values more than the standard value were

deleted from the scales. Total ten items were deleted, hence the five scales with 42 items were refined for the final test.

The main aim of this study was to test the initial generated questionnaire consisted of a developed scale with a statistically sufficient sample size and explore the magnitude to which the questionnaire produced reliable and valid scores. There total of 42 items, by following the 5 to 1 ratio method, that is, 5 respondents for one item, therefore a sample of 200 was sufficient to proceed with the exploratory factor analysis (Field, 2013).

To collect data from the faculty staff of four universities of Punjab, a survey research design was used. To select a sample of the study multistage sampling technique was used. In the first stage, nine public sector general universities were selected purposively out of 26 public sector universities of Punjab Province. In the second stage, four public sector general universities (namely Punjab University Lahore, G.C University Faisalabad, University of Agriculture Faisalabad, and University of Sargodha) were randomly selected out of nine public sector general category universities. In the third stage, a total of thirty-six departments ( 9 departments from each university) from four public sector general universities were randomly selected. Lastly, all male and female teachers were selected through a convenient sampling technique. A total of 300 participants participated in the final study (Males $=173$; Females $=127$ ) selected from four sampled universities. Collected data was transferred directly to an SPSS data file. 
The first part of the questionnaire was consisting of demographic information. The second part comprised of 5 scales consisted of 42 items.

\section{Exploratory Factor Analysis Results}

To explore the factors, the statistical tests EFA (Exploratory Factor Analysis) with the PCA (principal component extraction and Varimax rotation), Kaiser-Meyer-Olkin measure of sampling adequacy, Bartlett's test of sphericity, and reliability analysis with Cronbach's alpha, was performed (Field, 2013; Hair et al., 2009).

Two tests were conducted to check the sampling adequacy: First KMO Test as an initial solution, Principal component analysis (PCA) was performed on the 42 items in the questionnaire. The KMO, which measures that items are sufficient for each factor. Its value ranges from 0 to 1 , and the accepted index is greater than 0.6 value. Here, the KMO index was found at 0.896 hence satisfies the prerequisite condition of EFA. Further, Bartlett's test of sphericity was computed which was found significant $\left(\chi_{(861)}^{2}=6355.091, p<.01\right)$, which rejected the null hypothesis and hence the correlation matrix is significantly different from an identity matrix. These results ensure that exploratory factor analysis (EFA) can be applied to the data to explore the factors in it.

In the factor extraction methods, Principal Component Analysis (PCA) was used for this study (Eigenvalues greater than 1.0). This resulted in the extraction of six factors, explaining $52.57 \%$ variance (table 3) which can be considered as satisfactory in social sciences. The factors explained $12.87,2.937,1.778,1.708,1.446$, and $1.343 \%$ of the variance respectively.

Table 2. Number of factors extracted

\begin{tabular}{|c|c|c|c|c|c|c|c|c|c|}
\hline \multirow{2}{*}{ 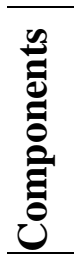 } & \multicolumn{3}{|c|}{ Initial Eigenvalues } & \multicolumn{6}{|c|}{$\begin{array}{l}\text { Extraction Sums of Squared Rotation Sums of Squared } \\
\text { Loadings } \\
\text { Loadings }\end{array}$} \\
\hline & Total & $\begin{array}{l}\text { \% of } \\
\text { Variance }\end{array}$ & $\begin{array}{l}\text { Cumulativ } \\
\text { e \% }\end{array}$ & Total & $\begin{array}{l}\text { \% of } \\
\text { Variance }\end{array}$ & $\begin{array}{l}\text { Cumulati } \\
\text { ve \% }\end{array}$ & Total & $\begin{array}{l}\% \text { of } \\
\text { Variance }\end{array}$ & $\begin{array}{l}\text { Cumulative } \\
\%\end{array}$ \\
\hline 1 & 12.870 & 30.644 & 30.644 & 12.870 & 30.644 & 30.644 & 4.848 & 11.542 & 11.542 \\
\hline 2 & 2.937 & 6.993 & 37.637 & 2.937 & 6.993 & 37.637 & 4.368 & 10.399 & 21.941 \\
\hline 3 & 1.778 & 4.234 & 41.870 & 1.778 & 4.234 & 41.870 & 4.049 & 9.639 & 31.581 \\
\hline 4 & 1.707 & 4.064 & 45.934 & 1.707 & 4.064 & 45.934 & 3.134 & 7.462 & 39.043 \\
\hline 5 & 1.446 & 3.442 & 49.376 & 1.446 & 3.442 & 49.376 & 3.030 & 7.214 & 46.257 \\
\hline 6 & 1.343 & 3.198 & 52.574 & 1.343 & 3.198 & 52.574 & 2.653 & 6.317 & 52.574 \\
\hline 42 & .129 & .307 & 100.000 & & & & & & \\
\hline
\end{tabular}

All the commonalities were examined and most of them were well in ranging from 0.70 to .40. As researchers suggest that communalities less than 0.40 should be eliminated (Schumacker \& Lomax, 2007). The factor loading for all the items was found to be more than 0.4. There were no items with cross-loading. Only one item (item14) had no significant loading on any factor it had a loading below the acceptable level of 0.40 and hence it was discarded from further list. This analysis thus showed that EFA provided a final solution in the form of a six-factor structure containing 42 items (items 7, $1011,18,21,34$, and 42) were excluded due to low communality). Item no 14 is low in the factor loading so the 14 items had been excluded from the scale of 42 items. Total 8 items have been excluded from the final list and the total scale comprised of 34 items and six factors.

Label Factors: To provide meaning to each factor, based on the core theme shared by its items, each factor was labeled (Field, 2013). Before labeling the factors, the researcher preferred to take the opinion of experts. Experts and supervisors were provided the suitable suggestions and review the final labels.

Evaluate Scale Reliability: Exploratory factor analysis was run and factor loading greater than 0.4 were selected. Moreover, against each item, the inter reliability was computed by using Cronbach's alpha statistic for all 6 scales and their respective items as well. Table 3 shows that Cronbach's $\alpha$ was above 0.70 (Hair et al., 2009) for sub-scales factor 1, indicating high reliability of the scale. 


\begin{tabular}{llll}
\hline Table 3. & Factor Loadings of "Improvement of Performance" scale & Communalities & Loadings \\
\hline Items & & & \\
\hline Factor 1: "Improvement of Performance" $\boldsymbol{\alpha}=\mathbf{8 2 7}$ & .566 & .604 \\
\hline 1 & $\begin{array}{l}\text { Teaching staff is encouraged to feel confident in raising } \\
\text { serious issues. }\end{array}$ & .589 \\
2 & $\begin{array}{l}\text { Teachers are more motivated to perform their duty. } \\
\text { Teachers produce the expected results better in the } \\
\text { chosen evaluation system. }\end{array}$ & .504 & .697 \\
& $\begin{array}{l}\text { the whistle-blowing procedure improves the } \\
\text { performance of the teaching staff. } \\
\text { whistle-blowing reporting provides appropriate } \\
\text { feedback and guidance for correcting the deficiencies of } \\
\text { teaching staff. }\end{array}$ & .606 & .728 \\
5 & $\begin{array}{l}\text { I am encouraged by the head to report immediately to } \\
\text { the head. }\end{array}$ & .461 & .507 \\
6
\end{tabular}

Table 4 explains the loading of each item and the internal consistency for factor 2 "Trust". The internal consistency for factor 2 "Trust" .867 Cronbach's $\alpha$ indicating high reliability of this factor. The loading of each item in this factor was found at a very good level (>0.4).

\begin{tabular}{|c|c|c|c|}
\hline Items & & Communalities & Loadings \\
\hline & Factor.2: "Trust" $\alpha=.867$ & & \\
\hline 1 & $\begin{array}{lllll}\text { My identity remains } & \text { confidential whenever I } \\
\text { complain/report. }\end{array}$ & .707 & .743 \\
\hline 2 & Information of the reporter remains confidential. & .619 & 677 \\
\hline 3 & All concerns are treated in confidence. & .556 & .590 \\
\hline 4 & $\begin{array}{l}\text { The head of the department takes appropriate action to } \\
\text { protect me when I raise a concern. }\end{array}$ & .649 & .559 \\
\hline 5 & $\begin{array}{l}\text { Whistle-blowing reporting increases my trust for } \\
\text { reporting. }\end{array}$ & .610 & .613 \\
\hline 6 & $\begin{array}{l}\text { Sometimes I report confidentially about corrupt behavior } \\
\text { within the organization. }\end{array}$ & .462 & .543 \\
\hline 7 & Reports are verified by the head of my department. & .503 & .489 \\
\hline 8 & An adequate support is provided to the reporter. & .529 & .451 \\
\hline
\end{tabular}

Table 5 confirms the loading of each item and the internal reliability for factor 3 "Awareness of Whistle-blowing reporting procedure". The internal consistency for factor 3 shows the .868 Cronbach's $\alpha$ which indicating the high internal consistency of this factor.

Table 5. Factor Loadings of "Awareness of reporting procedure" scale

\begin{tabular}{|c|c|c|c|}
\hline \multirow{2}{*}{\multicolumn{4}{|c|}{$\begin{array}{lc}\text { Items } & \text { Communalities } \\
\text { Factor.3: "Awareness of reporting wrongdoings procedure", }(\alpha)=.868\end{array}$}} \\
\hline & & & \\
\hline 1 & $\begin{array}{l}\text { I am satisfied with the selected confidential reporting } \\
\text { procedure. }\end{array}$ & .544 & .656 \\
\hline 2 & $\begin{array}{l}\text { The selected system of confidential reporting has a } \\
\text { significant impact on career development. }\end{array}$ & .561 & .560 \\
\hline 3 & $\begin{array}{l}\text { Present reporting procedure useful in enhancing the quality } \\
\text { of education in public sector universities. }\end{array}$ & .637 & .557 \\
\hline 4 & My department has a formal reporting place. & .576 & .565 \\
\hline 5 & $\begin{array}{l}\text { The Head of my department provides the opportunity for } \\
\text { his teaching staff to report (suspected) wrongdoing to the } \\
\text { committee. }\end{array}$ & .450 & .467 \\
\hline 6 & The reporting process in my department is unbiased. & .428 & .448 \\
\hline 7 & $\begin{array}{l}\text { There is a properly designed procedure of reporting in my } \\
\text { department. }\end{array}$ & .593 & .596 \\
\hline 8 & $\begin{array}{l}\text { There is a well-defined mechanism in my department for } \\
\text { cross verification of a report }\end{array}$ & .592 & .521 \\
\hline
\end{tabular}




\begin{tabular}{|c|c|c|c|}
\hline \multirow{2}{*}{$\begin{array}{l}\text { Table } 6 . \\
\text { ITEMS }\end{array}$} & \multirow{2}{*}{\multicolumn{2}{|c|}{ Factor Loadings of "Perception about reporting procedure" scale }} & \multirow[b]{2}{*}{ Loadings } \\
\hline & & Communalities & \\
\hline \multicolumn{4}{|c|}{ Factor.4: "Perception about reporting procedures" $\alpha=.798$} \\
\hline $\begin{array}{ll}\mathrm{Th} \\
\mathrm{we}\end{array}$ & $\begin{array}{l}\text { The Head of the department defines the ways to improve the } \\
\text { weaknesses of his teaching staff. }\end{array}$ & .745 & .613 \\
\hline $\begin{array}{l}\text { Th } \\
\text { th }\end{array}$ & $\begin{array}{l}\text { The Head of the department guides his teaching staff to improve } \\
\text { heir weaknesses. }\end{array}$ & .680 & .589 \\
\hline $\begin{array}{l}\mathrm{Tl} \\
\text { sta }\end{array}$ & $\begin{array}{l}\text { The Head of the department meets regularly with his teaching } \\
\text { staff to help out to minimize their deficiencies. }\end{array}$ & .632 & .708 \\
\hline 4 & Head of department advises teaching staff about their tasks. & .659 & .712 \\
\hline \multicolumn{4}{|c|}{$\begin{array}{l}\text { Table } 7 \text { illustrates the loading of items, Cronbach's alpha if item deleted, and the internal reliability of } \\
\text { factor } 5 \text { "Support" and factor } 6 \text { "Response to a report". The internal consistency of factor } 5 \\
\text { "Support" was found at } \alpha=.742 \text {, and factor } 6 \text { "Response to a report" was found at } \alpha=.808 \text {. The } \\
\text { loading of each item in these factors was very strong, all the items of these factors were loaded above } \\
0.4 \text { level. } \\
\text { Table 7. }\end{array}$} \\
\hline Items & & Communalities & Loadings \\
\hline \multicolumn{4}{|c|}{ Factor.5: "Support", $(\alpha)=.742$} \\
\hline 1 & I receive training related to my work when I need it. & .459 & .639 \\
\hline 2 & I am comfortable sharing my opinions at work. & .583 & .690 \\
\hline 3 & My head of department guides my work. & .522 & .556 \\
\hline 4 & My colleagues help me in difficult situations. & .556 & .719 \\
\hline \multicolumn{4}{|c|}{ Factor.6: "Response to a report", $(\alpha)=.808$} \\
\hline 1 & I receive all information that I need for work. & .640 & .579 \\
\hline 2 & $\begin{array}{l}\text { The Head of my department takes any action to control these } \\
\text { issues. }\end{array}$ & .679 & .606 \\
\hline 3 & $\begin{array}{l}\text { Sufficient resources are provided to me to enable the completion } \\
\text { of given tasks in time. }\end{array}$ & .525 & .507 \\
\hline 4 & $\begin{array}{l}\text { The Head of my department takes corrective action in response } \\
\text { to a report. }\end{array}$ & .573 & .547 \\
\hline
\end{tabular}

\section{Findings}

The findings and results of this study are discussed in terms of the four parts of the research objective addressed within the scope of this study as: "To develop a scale to measure the determining factors which influence the employees' decision to report wrongdoing". The first part was about "exploring the dimensions of whistle-blowing from literature review, interviews of university teachers and FGDs". And the second phase was to construct the items poo measuring the derived determining factors".

The first research part guided the qualitative phase of the study, which explored the dimensions of the whistle-blowing reporting procedure through focused group discussion and semistructured interviews. As a result of the qualitative data analysis, five themes emerged as the dimensions of the whistle-blowing reporting procedure; the items under these themes are generated from the finding of the qualitative part. The first theme Perception about Reporting Procedures that emerged as a dimension of whistle-blowing reporting procedure is perception and importance of whistle-blowing reporting contains 11 items (1-11) under this theme are generated from the interviewees' sentences and focused group discussion. The second theme is "awareness about whistle-blowing reporting system" in our public institutions. The 12 items (12-23) under this theme are generated. The third theme is "trust that the identity of the complainant would remain confidential". 6 items (24-29) under this theme are generated from the interviewees' sentences and focused group discussion. The fourth theme that is emerged from the interviews is "Belief that authority would take action in response to a report". 5 items (30-34) under this theme are generated from the qualitative part. The fifth theme that is emerged from the interviews is "Belief enough support would be provided to the complainant". The 8 items (35-42) under this theme are generated.

The third phase was about the initial refining of the scales through face and content validity and then measuring the inter reliability of the items of each scale. The Cronbach's alpha values for all the six dimensions were $.827, .867, .868, .798, .742$ and .808 respectively. All the values exceed the 
usually accepted minimum value of .6 , so it was concluded that the questionnaire demonstrates good internal consistency and therefore it generates reliable scores. Lastly, the fourth and final phase of the research objective was to conduct the quantitative study to develop the scale to measure the determining factors. During the item generating section, the findings of the first qualitative phase were employed to construct the items for each dimension.

Development of a scale is a lengthy process that starts with identifying the domain of the construct is comprised of dimensions. This is followed by generating items through which the construct will be measured and then conducting various statistical tests to validate the final scale. Therefore, findings showed that after the purification of new scale suggests that decision of whistleblowing or reporting the wrongdoings was influenced by six factors explored through EFA, namely: "Improvement of Performance", "Trust", "Awareness of Whistle-blowing reporting procedure", "Perception about reporting procedures", "Support and Response to a report". Final scale items were gained after various purification steps which involved various statistical analyses. The absolute outcome was a six-factor of 34 -items scale, suggesting that decision to blow the whistle was comprised of six dimensions.

\section{Conclusions and Recommendations}

It is concluded that the two-phase study, exploratory sequential mixed-methods study was found a better approach in exploring the determining factors. Subsequently, the questionnaire was also validated quantitatively, which reflected the six dimensions. Further, six major factors were explored in the current study as the determining factors of reporting wrongdoings.

This study provides various possible directions for research in the theoretical areas and statistical method. As a theoretical step, further extension of this work may be led towards the development of the grounded theory. To achieve this purpose, research should be led towards the model generation. Moreover, these factors in the model can be further verified by Confirmatory Factor Analysis (CFA) and structural equation modeling to assess the model fit of the dimensions. Also, future research can examine the relationship between the whistle-blowing reporting procedure and performance of employees, or other dimensions such as personality traits, culture of organization, job satisfaction.

\section{References}

Abbas, N., \& Ashiq, U. (2020). Why I don't blow the whistle? Perceived barriers by the university teachers to report wrongdoings Liberal Arts and Social Sciences International Journal (LASSIJ), 4(2), 84-97. https://www.ideapublishers.org/index.php/lassij

Appelbaum, S., \& Shapiro, B. (2006). Diagnosis and remedies for deviant workplace behaviors. Journal of American Academy of Business, 9(2), 14-20.

Brown, A. J., \& Head, B. (2005). Institutional capacity and choice in Australia's integrity systems. Australian Journal of Public Administration, 64, 84-95.

Carroll, A. B., \& Buchholtz, A. K. (2000). Organization and society (4 ed.). Mason: South-Western College.

Creswell, J. W. (2012). Educational Research: Planning, Conducting, and evaluating quantitative and qualitative research (4 ed.). New York: Pearson.

Creswell, J. W., \& Plano Clark, V. L. (2007). Designing and conducting mixed methods research. Thousand Oaks, CA: Sage publications.

Creswell, J. W., \& Plano Clark, V. L. (2011). Designing and conducting mixed methods research. Thousand Oaks, CA: Sage publications.

Creswell, J. W., Fetters, M. D., \& Ivankova, N. V. (2004). Designing a mixed-method study in primary care. Annals of Family Medicine, 2 (1), 7-12.

DeVellis, R. F. (2003). Scale development; theory and applications (2 ed.). Sage: California.

Donkin, M., Smith, R., \& Brown, A. J. (2008). How do officials report? Internal and external whistleblowing Whistleblowing in the Australian public sector. In A. J. Brown, Enhancing the theory and practice of internal witness management in public sector organizations (pp. 83-108). Canberra: ANU E Press.

Ewing, D. W. (1983). Do It My Way - or You're Fired. New York: Wiley.

Field, A. P. (2013). Discovering statistics using IBM SPSS statistics. (4th edition). Sage, London.

Hair, J., \& Van der Leeuw, S. (2009). Multivariate Data Analysis. London: Prentice-Hall, London. 
Hirschman, A. O. (1970). Exit, Voice and Loyalty: Responses to Decline in Firms, Organizations and States. Cambridge, MA: Harvard University Press.

Kaplan, S., Pope, K. R., \& Samuels, J. A. (2010). The effect of social confrontation on individuals' intentions to internally report fraud. Behavioural Research in Accounting, 22(2), 51-67. https://doi.org/10.2308/bria.2010.22.2.51

Keenan, J. P. (1995). Whistleblowing and the first-level manager: Determinants of feeling obliged to blow the whistle. Journal of Social Behavior and Personality, 10 (3), 571-584.

Mathews, M. C. (1987). Codes of ethics, Organizational behavior, and misbehavior. In W. C. Frederick, Research in Corporate Social Performance and Policy (Vol. 9, pp. 107-130). Greenwich, CT: JAI Press.

Miceli, M. P., \& Near, J. P. (1984). The relationships among beliefs, organizational position, and whistle-blowing status: A discriminant analysis. Academy of Management Journal, 27, 687705.

Miceli, M. P., \& Near, J. P. (1992). Blowing the Whistle: The Organizational and Legal Implications for Companies and Employees Issues in Organization and Management. Macmillan.

Miceli, M. P., \& Near, J. P. (1994). Relationships among value congruence, perceived victimization, and retaliation against whistle-blowers. Journal of Management, 20, 773-794.

Miceli, M. P., Near, J. P., \& Dworkin, T. M. (2009). A word to the wise: How managers and policymakers can encourage employees to report wrongdoing. Journal of Business Ethics, 86(3), 379-396.

Moustakas, C. (1994). Phenomenological research methods. Sage Publications.

Pittroff, E. (2016). Whistle-blowing regulation in different corporate governance systems: An analysis of the regulation approaches from the view of path dependence theory. Journal of Management \& Governance, 20(4), 703-727. https://doi.org/10.1007/s10997-015-9311-7

Rothschild, J., \& Miethe, T. (1999). Whistle-blower disclosures and management retaliation: The battle to control information about organization corruption. Work and Occupations, 26 (1), $107-128$.

Schumacker, R. E., \& Lomax, R. G. (2004). A beginner's guide to structural equation modeling. Psychology Press.

Seth, N., Deshmukh, S. G. \& Vrat, P. (2006). SSQSC: A tool to measure supplier service quality in the supply chain. Production Planning \& Control, 17(5), 448-463. DOI: 10.1080/0953728060 0741764

Stewart, D. (1996). Organization ethics. United States of America. McGraw-Hill: Companies, Inc.

Weinstein, D. (1979). Bureaucratic Opposition. New York: Pergamon Press.

Weiss, J. W. (2006). Organization ethics (4 ed.). Ontario: Thompson/South West.

Wortley, R., Cassematis, P., \& Donkin, M. (2008). Who blows the whistle, who doesn't and why? In A. J. Brown, Whistleblowing in the Australian public sector: Enhancing the theory and practice of internal witness management in public sector organizations (pp. 53-82). Canberra: ANU E Press.

Zipparo, L. (1999). Factors that deter public officials from reporting corruption. Crime, Law \& Social Change, 30, 273-273. 